\title{
Rituals of Solidarity in Castilian Confraternities*
}

\section{MAUREEN FLYNN}

$\mathrm{H}_{\text {istorians have long employed the term "individualism" to characterize }}$ the ethos of modern society. Jacob Burckhardt traced the birth of this ethos back to the fifteenth and sixteenth centuries in the Italian Renaissance's concern for the rights and talents of private man and since the publication of his book, ${ }^{1}$ many scholars, particularly Reformation historians, have enjoyed pursuing the various manifestations of individualism through such themes as "the Protestant ethic," "the spirit of capitalism," and "the frontier spirit." 2 What historians have not pursued with anywhere near the same degree of enthusiasm is "the spirit of corporatism" that preceded, and for a long time competed with, this modern ethic. We have yet to understand clearly how Medieval communities functioned when individuals were not guaranteed specific rights under the law and when their own self-identity was based on communal or familial rather than personal status.

The confraternities of late Medieval Leon-Castile offer a particularly rich and fruitful source of information on this unexplored terrain of traditional corporate life. In all parts of the old Spanish kingdom, people joined voluntary religious organizations which institutionalized their collectivist sentiments. Since all pious confraternities in Spain were required by the church to draw up sets of rules in order to inform episcopal authorities of their intentions, they have provided historians abundant written records of their internal affairs. Official confraternal statements tell us about the conventions that these voluntary associations observed, from mundane matters such as protocol for celebration of feast days and funerals to such formal concerns as membership obligations and spiritual aspirations.

It is apparent in these statutes that confraternities assumed many of the functions that are relegated today to civil administration and judicial bodies for the preservation of social order. Confraternities of late Medieval and 


\section{4 / Renaissance and Reformation}

early modern Castile were responsible for maintaining public peace through a variety of ritual mechanisms designed to ease personal tensions. They acted as police forces by disciplining the social conduct of their members and as lawyers and judges by arbitrating their own disputes. Like modern legal and ethical codes, their religious contracts attempted to shape people's character. While social harmony today depends upon the regulation of individual behaviour, in the past urban peace rested upon corporate rules. Members entered into voluntary agreements, sealed by oaths, to preserve the well-being of the community. Inside each confraternity, there was no distinction between separate rights of constituent members. The corporate personality took over, and all members became their brothers' keepers for the good of the whole. Each person understood that he or she shared responsibility in the welfare of the organic community.

A common spiritual quest provided the ideological cement for this institutional network of solidarity in Castilian villages and cities. The traditional Catholic vision of the gates of Heaven was crowded with familiar faces. Just as Dante caught the comforting glance of Beatrice among other acquaintances during his journey to Paradise in The Divine Comedy, so did pcople count on the support of the righteous both in heaven and on earth to assuage their fears.

In the early sixteenth century a Spanish widow, Francisca de la Peña, prepared herself for death and, in her will, prayed that through

faith, hope and charity in God and in his holy mercy that compassion will greet me; and in supplication of the always glorious Virgin Holy Mary, his mother, our intercessor, to whom I humbly pray, and to all the saints who are before the eternal throne of God, [I pray] that they be my lawyers and persuade my Saviour that he receive my soul....

At the Last Judgment, Francisca, like most of her contemporaries, did not imagine herself confronting God directly and alone; rather, she was escorted by the good wishes of loved ones on earth and by the good will of the blessed, to whom friendly recognition had been offered during her life.

In popular images of the Day of Reckoning, it was not the church as an institution, nor writs of pardon, nor quantifiable lists of indulgences, nor even clerics that were invoked to facilitate entry among the saved. The primary view expressed in testaments was that human companions would stand in defense of one's case.

The position of church leaders, by no means completely reconciled to this communal approach to salvation, nevertheless affirmed the ability of 
men and women to assist each other toward salvation. Medieval theologians beginning with Augustine acknowledged that, at death, friends and relatives could provide spiritual assistance to sinners. ${ }^{4}$ Augustine asserted that "it must not be denied that the souls of the dead are relieved by the piety of their living, when the sacrifice of their mediator is offered or alms are given in church."5 His references to "friends" and "saintly friends" who could obtain through their merits God's mercy on behalf of those for whom they prayed endorsed the sense of community and mutual support in early Medieval piety.

Church doctrine on the treasury of merits of the saints also sustained the collective pursuit of salvation among the populace. The church held that holy persons who lived in the Christian era had accumulated through their good works an abundance of grace that could be applied to fellow Christians. Saints of the past offered to the living a treasury of merits for their spiritual needs.

In theory all the meritorious deeds ever performed were at the disposal of the living, and all the good works and prayers accomplished by the living could be extended backward in time to the dead as well as forward to future generations. Perpetual reciprocity of merits and prayers between departed and living souls engendered a sense of communal immortality that transcended individual deaths. The community's ancestors depended on the supplications, penitences and indulgences of those on earth and thus the living shared responsibility in the fate of departed souls. In the judicial process of salvation private responsibility did not stand alone; the community helped redeem the faults of the dead. ${ }^{6}$

The idea that both the sanctified dead and the pious living could make reparations for the sins of others was powerful incentive to the formation of confraternities for mutual spiritual assistance. To townspeople as well as peasants of late Medieval and early modern Castile, confraternities offered a circle of companions who promised to provide spiritual aid upon their deaths. Outside the corporation, justification was a person's own responsibility and the way to salvation was solitary.

That many clerics as well as laity preferred the communal approach to salvation, sheltering themselves within the salvific programmes, is demonstrated by the sheer number of confraternities that operated in population centers. In the administrative capital of Valladolid, at least 100 confraternities have been estimated to have existed in the sixteenth century for a population of 30,000 . In Toledo, 143 confraternities have been identified 
among a population of $60,000 .^{7}$ The city of Zamora, located in the northeast of Spain's central plateau near Portugal, was possibly the most well-endowed in Europe, with 150 confraternities among a population which at its peak reached only 8600 residents in the sixteenth century. ${ }^{8}$ Confraternities were numerous in rural areas of Spain as well. We know, for example, that in the villages of the province of Cuenca, one organization existed among every 48 households. ${ }^{9}$ The influence of these organizations on their communities' spiritual life was exceptionally strong and succeeded in tying together inhabitants of diverse regional backgrounds and employment experiences.

By joining confraternities, Castilian residents gained communal protection and fortified their spiritual well-being with ties of fellowship. The confraternities designed requiem masses, prayer services, vigils over tombs and almsgiving programmes to assist the delivery of members' souls to heaven. They also created bonds of friendship with saints for assistance in salvation. By setting themselves up under the protection of special saints and honouring their feast days with masses, public processions and dancing, they established patronal rclations with heavenly beings capable of bestowing grace.

Patron saints in Castile were selected carcfully according to status or perceived sympathy for particular needs of members. More than a third of Zamora's 150 confraternities, for example, chose the Virgin Mary as their advocate, designing special honorific titles to distinguish her patronage among them. Santa María de la Vega, Santa María del Val de Mora, Santa María del Caño, and Santa María de la Cabana associated Mary with favourite natural settings around Zamora and domesticated her powers within private shrines. Other epithets attached to her name singled out special events in her life such as the Annunciation, the Purification, and the Visitation, or identified prized attributes-la Santa Caridad, la Misericordia, la Piedad. All these confraternities became Mary's children by adopting her various matronymics into their titles. Through language, they fulfilled their wishes to develop intimate relationships with the mother of God.

The populace fashioned the image of the Virgin into a patroness whose solicitude extended over the entire range of human needs. Unlike other saints, she was never identified as a special guardian against particular bodily ailments or natural calamities. She remained a universal symbol and could be called upon in many circumstances. R.W. Southern explains that, 
since the twelfth century, the Virgin's reputation was based on her willingness to extend aid to anyone who called upon her in need. "Like the rain," he comments, "this protective power of the Virgin falls on the just and unjust alike-provided only that they have entered the circle of her allegiance." 10 The notion that Mary, the epitome of human goodness, never exercised her compassion in a judgmental manner by making it contingent upon either the moral character of the supplicant or the seriousness of the cause was of utmost importance to members in search of a dependable ally to salvation. Mary's mercy softened the justice of her son, which was why her patronage was favoured over that of Christ, who frequently displayed, in popular imagery, the traditional appearance of a stern judge almost as unapproachable as God the father. Mary stood closer to human frailty and weakness and so received the first requests for assistance among mediators with the divinity.

Other holy patrons favoured by Castilian confraternities where those who enjoyed curative powers over certain diseases. There was Santa Agueda whose breasts were torn off by an enraged nobleman when she refused his sexual overtures. She was known to protect women of breast diseases when her assistance was solicited. San Blas protected against diseases of the throat while San Roque and San Sebastian were especially concerned about the bubonic plague. What all these holy mediators had in common was that they had morally conquered afflictions of the flesh in their lifetimes. It was this accomplishment that gave them special grace for assisting those feeble mortals who wept and wearied under the pressures of earthly existence.

To ensure adequate protection, members occasionally enlisted two, or sometimes more, advocates, one of whom was almost always the Virgin Mary. The Cofradia de Nuestra Señora de San Antolín y del Señor Santiago invoked the Virgin and the

blessed Apostól Señor Santiago, Light [and] patron of the Spanish lands, whom we take as lawyers in all our deeds so that they be guardians and defenders of our souls, bodies, and property, that we not perish by our errors, but that they guide us and place us on the right road of salvation.... 11

As insurers of brotherly aid and cultivators of saintly good will, these Spanish confraternities were carefully constructed death societies. They assumed collective responsibility for the guilt of individuals and established programmes that made reparations for sins. Through common oaths of fidelity to heavenly patrons, cofrades sought to ensure the salvation of 
everyone. The breaking of a communal oath to honour patron saints threatened the welfare of members' souls as well as those of past generations. Few dared risk eternal damnation by neglecting corporate obligations.

Not by sentiment alone, however, were these representations of the mystical body of Christ to survive on earth. An enormous amount of wealth went into fashioning corporate entities out of Castile's heterogeneous population. Canon law provided the necessary guidelines for acquisition and management of material goods. It designated that organizations dedicated to pious or charitable purposes were "moral persons," a juridical status that enabled their members to possess and administer property as a unit under the authority of the bishop. ${ }^{12}$ This status was obtained through formal decrees of the bishop or his delegate, and allowed confraternities to receive and distribute donations for pious causes. Groups that sought formal episcopal authorization were placed under the jurisdiction and protection of the cathedral chapter, and given the same privileges granted churches and other sacred places, including exemptions from royal tributes and excise taxes. With such favours, confraternities built up their estates and became major property owners.

Corporate land was donated principally by testators requesting that rental income be applied to charitable causes or liturgical services for the welfare of their souls. Since last wills and testaments had the force of civil law and the protection of the church, they furnished a stable source of financial support to the religious groups. ${ }^{13}$. Unless the specific requirements accompanying bequests were not being fulfilled, the church had no power to confiscate property holdings. Donors left their bequests in confraternal hands with the binding agreement that certain services be fulfilled, pious services that were incumbent on all cofrades, present as well as future. Members took solemn oaths of fidelity to these confraternal agreements with the dead, the breaking of which constituted a mortal sin. No greater commitment could have been given to those who wished to buy spiritual insurance. Cofrades incurred upon themselves the penalty of eternal damnation for failure to complete their vows on behalf of donors' souls. ${ }^{14}$

Another important incentive guiding individuals when they invested their wealth was that confraternities were obligated to protect possessions with communal funds. They assumed any legal costs that might be incurred in the process. The Cofradía de los Ciento in Zamora annually sent eight members to inspect conditions of its estates and to report back to the council in order to keep up with necessary repairs. ${ }^{15}$ As a group, members decided 
to rent property or convert rents into long-term leases. Such policies ensured donors that their property would be managed wiscly, for cofrades were generally concerned about maximizing corporate income. Only in the event that a fellow member required financial assistance might decisions be made differently. Brothers and sisters could be given priority over outsiders in renting corporate property even if the price that they were able to pay fell below other offers. For poor widows especially, this practice was a valuable form of welfare assistance and an important benefit of membership.

How much property was invested for the salvation of souls in Castile can only be guessed. What is certain is that the amount was sizcable. If we look at the larger pattern of land ownership in the kingdom of Leon-Castile, we see that church property as a whole expanded greatly between the eighth and thirteenth centuries, obtained in large part from small private estates turned over by individuals for just such purposes. During the Reconquest, southern Asturias, Leon, and Castile, particularly around the valley of the Duero river, had been repopulated by peasants and humble adventurers. Over a period of three or four centuries, a seigniorial regime such as that found in northern Europe replaced this early Medieval freeholding system. It was a massive transformation in land ownership that the eminent medievalist Luis G. de Valdeavellano attributes to the channeling into church hands of donations on bchalf of souls, or donationes pro anima. ${ }^{16}$ Of course not all this wealth went into estates of the confraternities, for in the tenth and eleventh centuries cathedral churches and monasteries received the vast majority of bequests, but in subsequent centuries lay-dominated organizations accumulated more and more of the donations. ${ }^{17}$ After immediate families, they were the most preferred group to which testators bequeathed property in the late Medieval period. ${ }^{18}$

In addition to income from testamentary bequests, confraternities received funds from entry fees, yearly dues, and fines for non-compliance with statutes. Members also regularly dropped small coins in confraternal almsboxes placed at convenient public sites to finance the illumination of chapel images. Confraternities of the Souls in Purgatory reserved special places for their boxes along stone bridges leading into the cities, converting the roadways into sacred passages reminding travellers of the transportation of souls through charity from one world to the next. When these proceeds fell short, appointed delegates asked for contributions among members or solicited donations from homes. 


\section{0 / Renaissance and Reformation}

In their concern for personal sanctification, the Castilian people elected to invest substantial portions of their wealth in corporate projects for the salvation of souls. As soon as private donations entered confraternal coffers they became a part of collective property and entered the exchange of charitable services that continuously reactivated graces among the community. Members distributed corporate revenue among themselves on special occasions, hoping to invigorate communal morale. Some groups made a practice of dividing half the entry fees of new members among the rest of cofrades to encourage attendance at initiation ceremonies. The confraternity of Valdés distributed part of its yearly gains to members on election day to induce members to come and vote for their officials. ${ }^{19}$ Others distributed money at celebrations of patron saint days and anniversary services, withholding it from those who did not attend without valid excuses. ${ }^{20}$ Corporate funds could also be used to regulate behaviour and prevent tardiness, a technique employed by the Cofradía de Nuestra Señora de la Visitación in refusing to give individual allocations to those who had not arrived for mass "before the raising of the chalice," or not "standing in their places with hats off for the sermon...." 21 The wealthy confraternity of the Racioneros, whose members were all beneficed clerics, offered a special policy to those who had served the organization for ten years by inviting them to give up their benefices and receive the rents and fruits of communal property. Non-veterans received bonus gifts of wheat and barley from confraternal lands after August's harvests and chickens in the Christmas season. ${ }^{22}$

Collective distributions of money were also common at burials, offered in the name of charity either by the confraternity or by the dead. The regular policy of the Cofradía de San Nicolás was to distribute 300 maravedis among members for attending funerals, provided that they were present from the time that the body was taken from its house until they returned back to the door for prayer. ${ }^{23}$ Testators offered charity to confraternities for distribution among participants at their own funerals. A donor to Nuestra Señora del Rosario allocated three reales to the confraternity's priest for saying mass and ringing the bell four times at his funeral, one real to the poor who were present, and six reales to attending members. ${ }^{24}$

Distributions of communal funds and offerings of gifts by testators to members served several different purposes. Practically the doles compensated individuals for time lost on the job while attending confraternal services. At funerals, the money covered ceremonial expenses of candles or 
torches and the mourning robes in which cofrades were dressed. The purpose explicitly stated for the doles, however, was more holy-minded than all this. They were expected to elicit memories of the dead and touch off prayers among members for the benefit of the departed's soul. Like other corporate ritual, the exchange of material goods was intended to foster spiritual solidarity.

As conceived in the minds of members, confraternities were microcosms of the ideal Christian world of love and equality among believers. They were managed to instill in individuals a spirit of cooperation and mutual support. Like all higher ideals, however, this world of brotherly love was easier to conceptualize than to practicc. The tactics adopted by confraternities to transform their ideals into reality were not without flaws and inconsistencies. Consider, for instance, the internal governance of a confraternity. Here we can see both the achievements and the failures of corporate policies.

The political structure was designed to uphold Christian belief in the equality of all souls before God. Members rotated official positions in order to prevent concentration of power, and they arrived at important decisions through consensus by vote. The mayordomo took charge of coordinating group activities. His duties included managing property transactions and other financial matters, presiding at meetings, enforcing statutes to ensure the performance of spiritual obligations, and organizing banquets, processions and feast day celebrations. Little status was attached to the position and, in fact, the work was considered so onerous that harsh penalties had to be imposed for refusing to serve once elected. The mayordomo held office for one year and received a salary from communal funds. Assisting him were other officials whose positions similarly held little prestige. The cotanero assumed the duties of calling members to attendance for meetings and services, and, if the society supported a hospital, regulated entry of patients. Accountants handled budgetary matters. Members shared remaining responsibilities, working either together or in turn depending on the character of the job at hand. In this manner, no single cofrade assumed a disproportionate amount of labour or prestige.

So far so good. But "Christian democracy" had its limitations, important limitations of which members may or may not have been aware. The denotation of the male gender in the terms brotherhood (hermandad) and confraternity (cofradia) was significant in internal politics. Although both men and women were admitted into membership in Spain, only men were 
allowed to hold governing positions and not infrequently women did not hold voting privileges. Indeed the only time that women enjoyed all the rights of members and fully exercised democratic principles was when they formed their own organizations. The way in which male colleagues dealt with them as incomplete creatures of God compelled the Cofradia de Nuestra Señora in the suburb of San Frontis in Zamora to demand firm independence from the control of men. Its female clientele formally mandated in statutes that "no man, not even the abbot or curate, may interfere by inspecting our confraternity." 25 The inconsistencics that they experienced in Christian attitudes about human equality were not unlike the experiences of women in late-eighteenth and nineteenth-century "republican" states of the west that restricted suffrage and office holding to men.

Among male cofrades, the notion that brotherhoods should be run democratically was conceived not so much with respect to equality of men and women as to equality of laymen and clerics. All precautions were taken to prevent a hierarchical distribution of power and prestige in favour of the priestly order. In old regime society the potential for clerical domination over lay brothers was an important concern. Most lay organizations limited the number of clerical members to two or three, or else requested that priests and friars enter as "laymen." The ecclesiastics were called upon to perform scheduled masses and attend at funerals, for which they received monetary reimbursement from confraternal funds that supplemented their parish salaries or prebendary stipends. Since the annual income of many clerics was notoriously low, service in confraternities could be a highly-prized position among them. Until the Council of Trent, cofrades maintained exclusive control over choosing their own clerical brothers, a privilege that helped create a system of lay piety relatively free from ecclesiastical manipulation.

Neither these cautious governing policies nor careful management of finances completely ensured that members of these holy alliances for salvation would cooperate together in perpetual peace and harmony. Elaborate and even stringent mechanisms had to be devised to maintain a sense of fellowship within the communities. The smooth functioning of these voluntary groups depended on the existence of good relations among cofrades, a goal that was carefully, and at times precariously, preserved. In all the confraternities of Castile, friendship was formally cultivated, tested and ritualized. Interaction among members was prescribed rigorously, to 
the point of being subject to written decree and enforced by officials. Extreme care was taken to ensure that incoming members would not disrupt this harmony. When a person wished to join a confraternity, three council sessions were held to discuss the aspirant's character and explore reactions of cofrades to the admission of the new member. Anyone who wanted to enter, according to the Cofradía de Santo Cristo de la Agonía, "must be a gentle and pacific person, and of good conduct, in order to avoid occasion for scandal and tumult, or the altering of the peace and blessed union that all of us, as catholic Christians, are obliged to maintain." 26 If any member objected to a candidate, admission proceedings were terminated or acceptance was delayed until the objection was withdrawn. The Cofradía de Nuestra Señora de San Antolín specified in 1503 that if any cofrade complained that a candidate "is his enemy, that he [the candidate] not be received until they become friends, because it is not right that among brothers who are to live in concord there be hostility and discord."27

Aristocratic confraternities that required strict purity of blood and noble status for membership appointed special committees sworn to secrecy to review testimonies on the qualifications of candidates. Once this step was successfully completed, admittance of candidates passed into the hands of members for majority, or in some cases, unanimous, approval.

General meetings were dangerous opportunities for disagreements and harsh words between cofrades and everything possible was done to ensure that discussions proceeded smoothly. To prevent persons from talking simultaneously and to ensure that each would have the opportunity to voice his opinion, a vara or rod symbolizing authority and justice passed from hand to hand of those who spoke. Cofrades of San Antonio Abad in the church of San Antolín recommended that in their meetings they be

quiet, peaceful and calm, and that no-one carry on noisily nor cause a disturbance; and if the mayordomo should see anyone in anger, or beginning to fret or raise a commotion, he is to take the precaution of allowing him to speak. He who speaks must do so with the vara in hand and without passion, and if he be ordered to be quiet, he must be quiet; and if he remains pertinacious and rebellious and obstinate after being reprimanded, he should be punished by the Council.... ${ }^{28}$

Fines and penalties confronted the audacious cofrade who unsheathed the sword or shouted obscenitics in anger. In order to prevent violence, aristocratic brotherhoods forbade the carrying of arms to council meetings, masses, and burials. Mcthods of correcting slander or injury perpetrated by 
one cofrade on another had to be devised because members did not always meet standards of sociability which, as one organization put it, compels "all we cofradas to be very sisterly and honest, and not rambunctious." 29 Harsh words, squabbles and name-calling between members were brought before mayordomos and offenders were "fraternally castigated."

Morality was controlled, and to a large extend perceived, within the context of collective devotion. Artisans who organized the confraternity of San Cucufate enforced fines of a pound of wax for insulting each other at council meetings; they insisted upon two pounds for second incidents and finally threw offenders out of the meeting for further transgressions while demanding that apologies be made to injured parties. ${ }^{30}$ Cofrades of San Nicolás reacted in indignation if one of their group criticized the confraternity or the proceedings of its council whether in the heat of anger or in a completely sober temper. If cofrades went about saying that they no longer wanted to be part of the group, they were charged 25 pounds of wax each time that the sentiment was uttered and, to top matters off, they were not permitted to leave without the consent of all the members. ${ }^{31}$

The confraternities served as private guarantors of law and justice within their community, taking opportunities for vengeance out of the hands of individuals. According to the rules of the Cofradía de Nuestra Señora de la Antigua in 1566, if one cofrade injured another,

the aggressor is to ask pardon from the entire council and the injured one, and to be friends. Furthermore, if the offense were grave and the aggrieved does not want to forgive, our cofradia will raise the hand for punishment... and if the misdeed merits, and the aggrieved persists in holding back pardon. the council can freely expel J the aggressor from the organization] and receive another in his place. ${ }^{32}$

A member of Santa María Tercia y Santa Catalina would bring up complaints of mistreatment or disrespectful dealing by another member before his general council, which named four members to examine the case. If found culpable, the offender was ejected from the group for four years. ${ }^{33}$

In their preoccupation with social harmony, confraternities performed religious rituals designed to appease tensions. At group activities such as pilgrimages and feasts, members were required to be on good terms. The Cofradía de Nuestra Señora de San Antolín fined those who were not in a state of friendship before leaving on its yearly pilgrimage, while cofrades of the Santa Cruz in the village of Villalpando made it a practice before sitting 
down to their annual Palm Sunday meal to offer a communal pardon for all ill intentions and injuries that had been committed. ${ }^{34}$

Concern to maintain peace also carricd over into their private lives. Some confraternities required that members not take in domestic servants or hired hands of another cofrade without consent. No legal suits could be filed against another member of one's confraternity, for disputes were handled by the society. Nor could one cofrade buy a bond weighing over another.

Such artificial measures may have seemed doomed to generate a mere facade of fellowship, but a more hearty congeniality was fostered among members by common festivities, banquets, and processions. These shared activities contributed to the formation of a collective mentality. Cofrades prayed for each other at masses and identified their fortunes with a common patron saint. They revered the same statue and guarded the same relics. In the penitential confraternitics, members even wore the same dress for processions, donning long hooded robes that covered the face and made each of them an anonymous participant of one mystical body recognizable to the public only by corporate banners.

Their central communal event was the annual banquet that celebrated the spirit of brotherhood among members. According to the church, "this fellowship or covenant meal...externalised the supernatural faith of the participants." 35 It was a ritual act that emulated the Last Supper when "our Redeemer, in an attempt to show his disciples a sign of his love, wished to dine with them." Confraternities recognized that their meals served the purpose of nurturing bonds of charity and love among communicants. The confraternity of San Ildefonso asserted that "in accordance with our humanity, love always increases at social gatherings and banquets." Every year members feasted on the day of its patron saint "so that love and charity grow among us." 36

Municipal police might view such disingenuous claims more cynically, for confraternal festivities were frequently the occasion for rowdy dancing and brawling in the streets. Mutual love and joy created in an atmosphere of food and drink did not always coincide with law and order and the city council from time to time was forced to ban communal feasting in the interest of public peace. Christian ideals here as elsewhere did not translate into reality. Corporate disciplinary mechanisms failed to contain conflict in all circumstances, as quarrels over precedence in processions also attest. But it is not surprising that cofrades occasionally failed to obey the spirit of their laws; and indeed the remarkable fact is that they did demonstrate a 
more constant commitment to keep it. The deepest bonds of fellowship, ones that were rarely violated, appeared in the welfare programmes for the relief of sickness and poverty and the salvation of souls. The sick and dying called to their sides, around their beds or caskets, the brothers and sisters of their confraternities. To be "accompanied" was one of the most frequent and heartfelt concerns of testators, and one of the main reasons why they joined confraternities and donated generously to them at the end of their lives.

For it is certainly true that however short of their goals these alliances may have fallen, their corporate ritual made a concerted effort to realize within the microcosm of membership the spiritual ideals of brotherhood and social equality. Their constitutions and oaths on matters of policy denote not the vertical paternal contracts characterizing Medieval kingship and fcudalism but horizontal fraternal agreements among equals. They were the first self-consciously democratic organizations in Castile, founded upon the religious concept of universa fraternitas. The confraternities constituted one of the clearest institutional expressions of religious ideals in society, matched only perhaps by the monasteries.

\section{University of Maryland}

\section{Notes}

* Parts of this article have been published in my book, Sacred Charity: Confraternities and Social Welfare in Zamora, 1400-1700 (Macmillan Publishers, Ltd. and Cornell University Press, 1989).

1 Jacob Burckhardt, The Civilization of the Renaissance in Italy, first published in 1860 under the title Die Cultur der Renaissance in Italian.

2 Max Weber, The Protestant Ethic and the Spirit of Capitalism (1904/05). See also in this regard R. H. Tawney, Religion and the Rise of Capitalism (London, 1912).

3 Archivo Histórico Provincial de Zamora, Desamortización, caja 108.

4 Augustine, The City of God, book 21, chapter 27. See also Hugh of Saint Victor, On the Sacraments of the Christian Faith (De Sacramentis), book 2, part 16. English version by Roy J. Deferrari (Cambridge, Massachusetts: Medieval Academy of America, 1951).

5 Augustine, Enchiridion, 110. Assistance offered by the living was efficacious only for moderate sinners however, according to Augustine. Those who committed mortal sins were incapable of being saved.

6 John Bossy's study of the social consciousness of the mass examines the process whereby communicants offered prayers and charity for the benefit of souls in purgatory during services. "Essai de Sociographie de la messe. 1200-1700," Annales, E.S.C. 36 (1981): 44-70.

7 Teófanes Egido, "Religiosidad popular y asistencia social en Valladolid: Las Cofradias Marianas del s. XVI," Estudios Marianos 45 (Salamanca, 1980): 198; and Linda Martz, Poverty and Welfare in Ilabsburg Spain (Cambridge, 1983), p. 159.

8 For a complete list of these 150 confraternities, see my Ph.D. dissertation, "Confraternities and Social Welfare in Late Medieval and Early Modern Zamora" (University of Wisconsin-Madison. 1985). Beyond the Pyrenees, confraternities appear to have been less 
numerous than in any of the Spanish provinces. In sixteenth-century Florence, 75 confraternities have been cited among a population of 59,000 in Benedetto Varchi, Storia fiorentina, (Florence: Salani, 1963); In Lyon, 68 are noted for a population that varied between 45,000 and 65,000 in the sixteenth century by Natalie Davis, "The Sacred and the Body Social in Sixteenth-Century Lyon," Past and Present, 90, 51. The northern European city of Lubeck, with 25,000 residents in 1400 , had at least 67 confraternities according to Monika Zmyslony, Die Bruderschaften in Lübeck bis zur Reformation (Kiel, 1977).

9 Sara Tilghman Nalle, "Religion and Reform in a Spanish Diocese: Cuenca, 1545-1650" (Ph.D. dissertation, Johns Hopkins University, 1983), p. 225.

10 R.W. Southern, The Making of the Middle Ages (New Haven, 1953), p. 248. Tales of the miracles of the Virgin show that she did not withhold her aid from thieves, vagabonds and miscreants of any sort. See, for example, the codices of the Cantigas de Santa Maria in the Escorial: Jesús Montoya Martinez, Las colecciones de milagros de la Virgen en la edad media: el milagro literario (Granada. 1981). pp. 152-53; and Johannes Herold, Miracles of the Blessed Virgin Mary, ed. Eileen Power (London, 1928).

11 "Ordenanzas de Nuestra Señora de San Antolin y del Señor Santiago de la Ciudad de Zamora. Año de 1503," in E. Fernández-Prieto, Nobleza de Zamora (Madrid, 1953), pp. 33-45.

12 Canon 691 in the Corpus Juris Canonici.

13 Church councils of the early Middle Ages decreed that those who failed to distribute bequests in alms according to the wishes of the dead would be excommunicated; and the Justinian Code confirmed rights to the will of the dead (Codex Justinianus, 1, 3, 45); the sentiments of conciliar decrees were repeated by Canonists, see Gratian's Decretum, Canon 9, "Qui oblationes," and Canon 11, "Clerici vel saeculares"; and Huguccio, Summa ad Dict., 88 , Canon 5. The Siete Partidas enforced the fulfillment of testamentary works in partida $6, t i t$. 10, leyes $1-6$.

14 The church was heartily opposed to this practice, arguing that lay people did not have the right to designate what did and did not constitute a mortal sin. Throughout the late Middle Ages it attempted to eradicate these confraternal oaths.

15 Proving negligent on many occasions. Ordenanzas, Archivo de la Mitra de Zamora, Archivo de los Ciento, Constituciones de la Cofradía de los Cientos, ff. 26-28.

16 Valdeavellano, Curso de Historia de las Instituciones Españolas, p. 247. Sánchez-Albornoz’s study of church cartularies in the tenth and eleventh centuries anticipated the conclusions made by his student, Valdeavellano, in Despoblación y repoblación del Valle de Duero (Buenos Aires: 1966), pp. 284-89 and in El régimen de la tierra en al reino Asturleones hace mil años (Buenos Aires, 1978), pp. 19-57, where he stressed the spiritual motivations behind the hundreds of donations to monasteries which he had examined.

17 In the Catastro del Marqués de la Ensenada, a register of property, salaries, and other income of individuals and religious institutions in the provinces of Castile, compiled in the mid-eighteenth century, we have the opportunity to calculate the amount of land held by the various religious institutions, including confraternities and hospitals.

18 The early church fathers recommended that one-half of one's estate, "the share of the soul," be given for pious purposes as donations to church institutions or alms to the poor, and these were frequently administered by confraternities. Augustine directed that bequests in alms should not exceed a son's share if children survived. Gratian returned to Augustine's position, although other canonists argued that Augustine's intention had been to dissuade but not to prohibit donations larger than an inheritor's share. Roman law imposed definite minimal limits on inheritances for children (pars legitima) of one-half to one-third of estates. See Michael M. Sheehan, The Will in Medieval England (Toronto, 1963), pp. 8,123 , and 127. In 1505 , Spanish secular legislation restricted the amount that could be bequeathed for the welfare of one's soul to one-fifth of one's estate (Leyes de Toro, leyes 12 and 32): and according to Moralists (not stated in Canon Law), testators could leave up to one-third of the "legitimo," and the "mejora," (usually used to favour one son in a 
system in which primogeniture was not encouraged) to the church for pious causes so long as it would not harm descendants. Natural law required that parents give to their children only that which they needed. If testators left more than one-third to the church, and inheritors complained in court, the will of the civil judges prevailed.

19 "porque mejor se junten," Archivo de la Mitra de Zamora, uncatalogued, Ordenanzas de la Cofradía de Nuestra Señora de la Anunciación, f. 8v, 1531. For locating the statutes of this confraternity, common called "Valdes," I am grateful to Father Ramon Fita Revert, personal secretary to the Bishop in Zamora.

20 "Ordenanzas de la Cofradia de San Nicolás," in Fernández-Prieto, Nobleza de Zamora, p. 383 , tít. IX and $X$.

21 Archivo de la Mitra de Zamora, Archivo de los Ciento, Ordenanzas de la Cofradía de Nuestra Señora de la Visitación.

22 Archivo de la Mitra de Zamora. Archivo de los Ciento, Ordenanzas de la Cofradía de los Racioneros, f. 3, tit. 3 and f. 10, tit. 11.

23 "Ordenanzas de la Cofradía de San Nicolás," in Fernández-Prieto, Nobleza de Zamora, p. 390 , tit. 31 .

24 Archivo Particular de Don Enrique Fernández-Prieto, Orden 1891, no. 7, Estatutos de Nuestra Señora del Rosario y Purificación, 1544; tít. 13 and 14.

25 Archivo Parroquial de San Frontis de Zamora; Libro 38, Ordenanzas of 1630.

26 Archivo de la Mitra de Zamora, Archivo de Santa María de la Horta, Santo Tomás, no. 17. The ordinances of Santo Cristo are from the eighteenth century.

27 Archivo Particular de Don Enrique Fernández-Prieto, Estatutos de la Cofradia de Nuestra Senora de San Antolín.

28 Ordenanzas de la Cofradia de San Antonio Abad of Zamora, 1591, transcribed by José del Carmen and published in 1928, a copy of which was kindly given to me by the current mayordomo.

29 Archivo Parroquial de San Frontis, Libro 38, Ordenanzas de 1630.

30 Archivo de la Mitra de Zamora, Archivo de Santa María de la Horta, Tomas Apostál, Libro 16, Ordenanzas de la Cofradía de San Cucufate, 1509.

31 Ordenanzas de la Cofradia de San Nicolás, in Fernández-Prieto, Nobleza de Zamora, pp. 391-92.

32 Archivo de la Mitra de Zamora, Archivo de los Ciento, Ordenanzas de la Cofradía de Nuestra Señora de la Antigua, 1566.

33 Archivo de la Mitra de Zamora, Archivo Santa María de la Horta, Santa María de la Horta, no. 41(1) Ordenanzas de la Cofradía de Santa María de Tercia y Santa Catalina de 1552 , ordinance no. 10.

34 "Ordenanzas de Nuestra Señora de San Antolin...," in Fernández-Prieto, Nobleza de Zamora, and the "Estatutos de la Cofradia de la Santa Cruz," in Luis Calvo Lozano, Historia, statutes of 1580 , pp. 240-41.

35 The New Catholic Encyclopedia, "Meals, Sacred"; and Emile Durkheim, The Elementary Forms of Religious Life, trans. by Joseph Ward Swain (New York: Free Press, 1965), p. 378.

36 Archivo de la Mitra de Zamora, Ordenanzas de la Cofradia de San Ildefonso, p. 518. 